術前 4 年間経過を観察した粘液性膵囊胞腺癌の 1 切除例

\begin{tabular}{cccc}
\multicolumn{8}{c}{ 本荘第一病院外科, 同 消化器科* } \\
佐 藤 & 勤 & 鉿 木 克 彦 小 松 寛 治* \\
村 田 & 誠* & 若 松 秀 樹* \\
& & & \\
& & 秋田大学第 1 外科
\end{tabular}

浅沼義博南條博小山研二

4 年間経過を観察したのち，膵全摘術を行った粘液性膵变胞腺癌の 1 例を経験し，そ の発生過程, 治療方針について検討した. 患者は78歳, 女性で, 1987年に他医で腹部 CT,

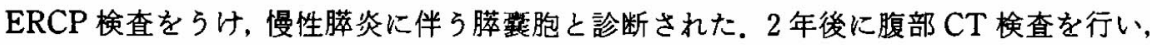
著変なしと判断され経過観察されていた。さらに 2 年後に当院で精査を行い, 膵頭部の 膵琵胞腺癌と診断し, 手術を施行した。術式は膵尾部まで裹胞が散在したため, 膵全摘 術を選択した。過去の検查所見と切除標本上を検討し，膵頭部の分枝払張膵管から発生 した腫瘍であり，過去 2 年間で癌の発育と同時に簑胞も増大した。 また，病理組織学的 に, 高分化型腺癌の乳頭状增殖像の他に異型度の低い腺腫の部分, 上り異型度の高い細 胞の丈の低い乳頭状堌殖像など分化度の異なる部分が共存し，本症例の発生は腺腫から の癌化と考えられた。

索引用語：粘液性脺衰胞腺癌, 慢性膵炎, 膵全摘術

はじめに

画像診断の進歩に伴い膵变胞性疾患が多数発見され るよらになり，その分類や臨床的対応について論じら れる機会が増えつつある ${ }^{122)}$. 今回, 初回検査で慢性膵 炎に合併する膵黄胞と診断され，4年後に切除された 粘液性膵旁胞腺癌を経験した。この症例をもとに，そ の発生過程, 治療方針について検討する.

$$
\text { 症例 }
$$

患者：78歳，女性.

主訴：特になし。

既往歴：17年前から糖尿病でインスリン治療を継続 中. 7 年前子宮下垂にて子宮摘出.

現病歴：1987年に他病院での腹部 CT 検查（図 1) て脺頭部から体部にかけて低吸収域を数個認め, 膵 胞が疑われた．この時の腹腔鏡検查では，脺頭部の腫 大ならびに膵体部に複数の小囊胞を認めた。 $\mathrm{ERCP}($ 図 2) では，膵頭部から体部にかけて主膵管が拡張し， その分枝打よび尾部に襄胞状に拻張した部分を認め た．末梢血検査では，WBC $4,100 / \mathrm{mm}^{3} ，$ RBC $409 \times$

1992年 7 月 16 日受付 1993年 1 月29日採用

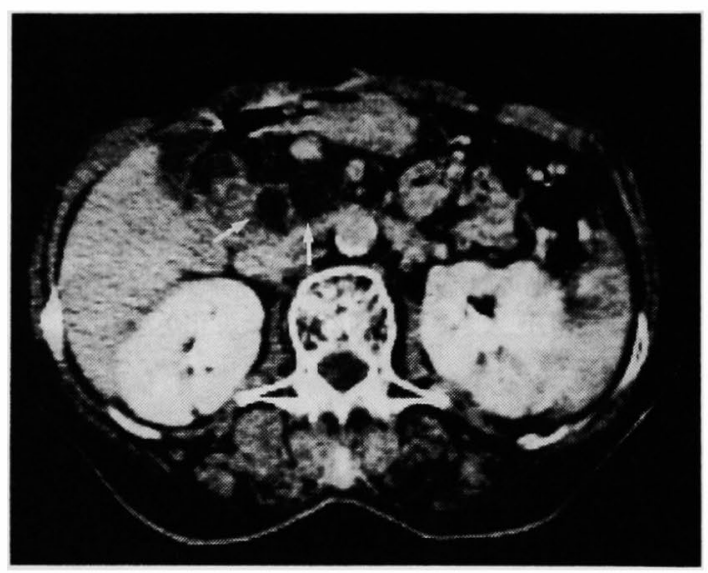

図 14 年前の腹部 CT 所見 : 膵頭部から体部にかけ て衰胞を認める（矢印）。

$10^{4} / \mathrm{mm}^{3}$, Hb $12.4 \mathrm{~g} / \mathrm{dl}$, Ht $36.4 \%$, Plt $10.2 \times 10^{4} /$ $\mathrm{mm}^{3}$, 血液中の CA19-9は31U/ml であった。 また, 腹 腔鏡下で穿刺採取した襄胞液の細胞診はClass Iであ ク，悪性を示唆する所見は認めなかった。 その 2 年後の 1989 年 4 月に, 当院を受診し, 腹部 CT 


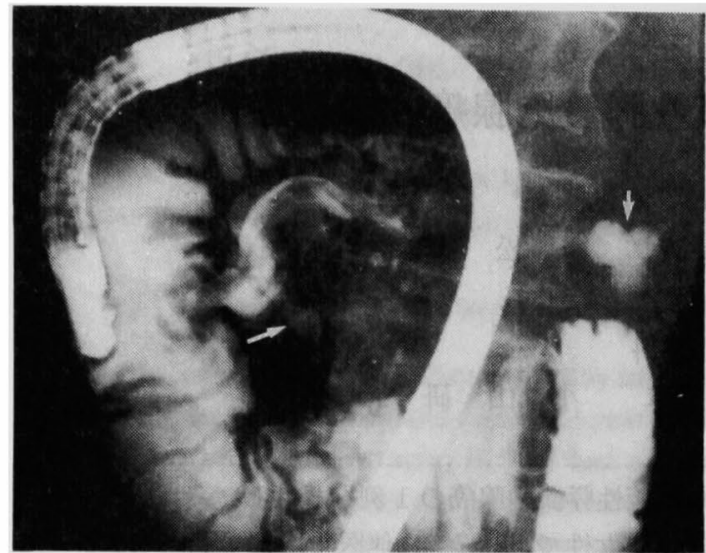

図 24 年前の ERCP 所見：膵頭部から体部にかけ て脺管が拡張し，その分枝と尾部に震胞状払張を認 める (矢印).

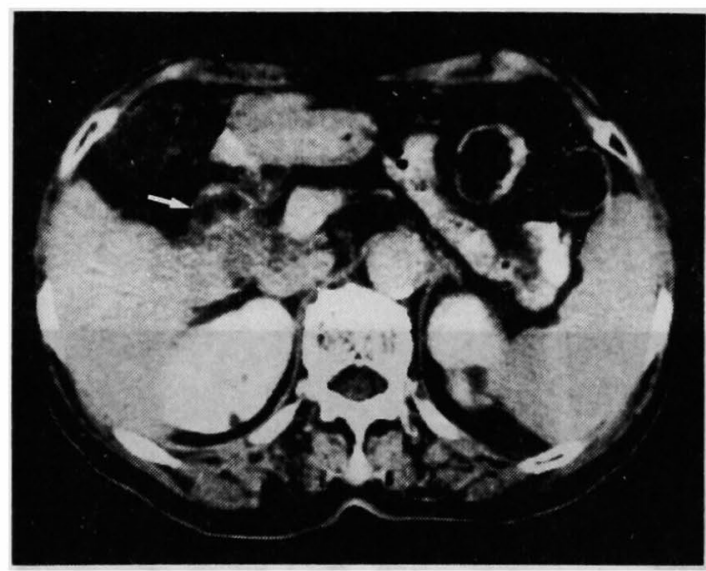

图 32 年前の腹部 CT 所見：膵頭部に重胞を認める が (矢印)，大きさ 4 年前のるの変化がない。

検査を行い，図 3 のごとく膵頭部の腫大および脺頭 部から体部に多発性鸾胞を認めたが，前回の他医での 検查所見と著変がないと判断し，経過観察することに した.

1991年10月に食欲不振，めむい感を訴えて来院した ので，精查のために入院した。

入院時現症, 検査成績：体格は小, や世型で, 結膜

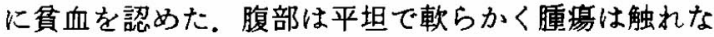
かったが，脾を 2 横指触知した，検查成績を表 1 に示 す。末梢血検查で觬血がみられたが ERCP 施行時に Vater 乳頭部からの出血が確認されており, 腫境から の出血によるものと考えられた。ま，汎血球减少を
表 1 入院時検查成績

\begin{tabular}{|c|c|c|}
\hline \multicolumn{2}{|c|}{ 末梢血検査 } & 出血凝固： \\
\hline RBC & $240 \times 10^{4} / \mathrm{mm}^{3}$ & Bl. time $2.0 \mathrm{~min}$ \\
\hline $\mathrm{Hb}$ & $5.9 \mathrm{~g} / \mathrm{dl}$ & $11.5 \mathrm{sec}$ \\
\hline $\mathrm{Ht}$ & $18.3 \%$ & $33.0 \mathrm{sec}$ \\
\hline WBC & $2300 / \mathrm{mm}^{3}$ & $2.5 \mu \mathrm{g} / \mathrm{ml}$ \\
\hline Plt & $6.3 \times 10^{4} / \mathrm{mm}^{3}$ & $162 \mathrm{mg} / \mathrm{dl}$ \\
\hline \multicolumn{2}{|c|}{ 生化学検查： } & 胜摆マーカー： \\
\hline TP & $5.8 \mathrm{~g} / \mathrm{dl}$ & CEA $\quad 0.8 \mathrm{ng} / \mathrm{ml}$ \\
\hline GOT & $19 U / 1$ & CA19-9 $23 \mathrm{U} / \mathrm{ml}$ \\
\hline GPT & $15 \mathrm{U} / 1$ & Elastase $\quad 56 \mathrm{ng} / \mathrm{dl}$ \\
\hline LDH & $402 \mathrm{U} / 1$ & Dupan-2 $<25 \mathrm{U} / \mathrm{ml}$ \\
\hline T. Bil & $0.3 \mathrm{mg} / \mathrm{dl}$ & \multirow{7}{*}{ 検尿：㟟常なし } \\
\hline AMS & $34 \mathrm{U} / \mathrm{I}$ & \\
\hline BUN & $14 \mathrm{mg} / \mathrm{dl}$ & \\
\hline Crea & $0.6 \mu \mathrm{g} / \mathrm{dl}$ & \\
\hline $\mathrm{Na}$ & $142 \mathrm{mEa} / \mathrm{l}$ & \\
\hline K & $4.9 \mathrm{mEq} / \mathrm{l}$ & \\
\hline $\mathrm{Cl}$ & $109 \mathrm{mEq} / \mathrm{l}$ & \\
\hline
\end{tabular}



図 4 今回の腹部 CT 所見：膵頭部の萁胞(矢印) は増 大し，内部に充実性の部分を認める、脺体部にも毫 胞が存在し、また，脾腫を認める。

認めたため，骨䯣生検を行ったが異常は認められず, 脾機能え進に上るものと考兄られた。腫瘍マーカーは 全て正常範围内であった。 また， 4 年前の時点では， インスリン必要量は14単位/日であったが, 現在は24単 位/日を注射していた。

腹部 CT 所見(図 4)：膵頭部に径 $6 \mathrm{~cm}$ の裹胞性病変 を認め,さらに袈胞内に充実性の部分の発育が確認さ れ，膵衰胞腺癌が疑われた，体尾部にも小赛胞を多数 認め, 主膵管は尾部まで拡張していた。

腹部血管造影 (図 5 )：膵頭部に $3.5 \times 2.0 \mathrm{~cm}$ の腫場 


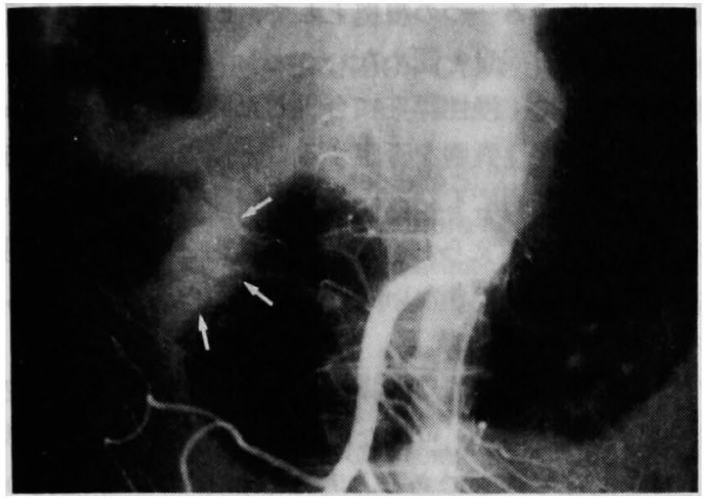

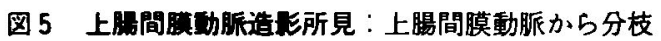
する腈頭部フーケードの末梢に細な畽湯血管と尰 霰瀑染像（矢印）を認める。

浱染像を認めた。また，門脈が右方から王排されてい た.

なお ERCP 施行時にV Vater 乳頭から凝血塊の排出 を認め、乳頭へのカニュレーションは行わなかった。 以上より, 脺震胞腺癌と䛦断し, 平成 4 年 1 月 10 日, 手術を施行した。

手術所見：脺頭部から体部にかけて，超熖卵大の硬

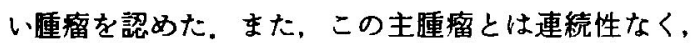
膵体部から尾部にかけて径 $1.0 \mathrm{~cm}$ 程度の妻胞が 5 ～6 個存在していた。当初は，脺頭十二指腸切除を行 ら方針であったか，尾部まで貿胞が散在していたため 脺全摘術を行った，膵癌取扱い規約によると，Phb， sup-inf, $\mathrm{T}_{3}$, tumor-forming type, $\mathrm{S}_{0}, \mathrm{Rp}_{0}, \mathrm{CH}_{0}$, $\mathrm{DU}_{0}, \mathrm{~V}_{0}, \mathrm{~A}_{0}, \mathrm{H}_{0}, \mathrm{~N}_{2}(-), \mathrm{M}(-)$ であった。 な お，門脈圧充進を疑わせる側副血行路の発達は認めな かった.

切除標本 (図 6)：脺頭部の腫瘤は， $7.0 \times 6.0 \times 5.0$ cmのムチンを内包する童胞性隀瘍で，割面では图 6 のごとく乳頭状の增殖が著明で内部に出血，一部壊死 を伴っていたままた，荲胞は主腈管と交通しており， 末梢の膵管は搪張し，膵管壁か肥厚していた，蕫胞内 の出血は, 膵管, Vater 乳頭を経て十二指腸内に達して いた。また，摘出脾の重量は460g であった。

病理組織像（図 7)：図7aのごとく粘夜産生を有す る円柱状の癌細胞の内腔への乳頭状增殂を認め, 取扱 い規約によると，INF $\alpha 、 \mathrm{y}_{0}, \mathrm{v}_{0}, \mathrm{ne}_{0}, \mathrm{du}_{0}, \mathrm{~s}_{0}, \mathrm{rp}_{0}$, $\mathrm{pvsp}_{0}, \mathrm{a}_{0}, \mathrm{pw}(-), \mathrm{ew}(-), \mathrm{n}(-)$ であった。 た，周囲の拡張した膵管に異型を有する円柱状細胞の 丈の低い、乳頭状增殖を認めた(図 $7 \mathbf{b})$ ）。た，異型度の



图 6 切除標本所見(割面): 趞胞内に充実性腫埸の乳 頭状発育か著しく，一部は，出血，壊死に陥ってい る。


図 7 病理組織像：a，粘液産生を有する円柱状癌細 胞からなる上皮の乳頭状腺癌の増殖像．b，周囲の 払張した脺管内に認められた丈の低い、異型細胞の増 殖像.c.一原の円柱上皮で襄らちされた異型のない 妻胞像（萇胞腺腫）。 
ない一層の円柱上皮に裏らちされた胞の部分も存在 した（図 7c)，膵実質は萎縮が著明で，線維化，小円形 細胞漫潤が目立つ慢性膆炎の像であった。

術後経過：術直後はブドウ糖 $5 \mathrm{~g} に$ 対しレギュラー インスリン 1 単位の割合で点滴ボトル内に混入し，血 㜍值は200 - 250mg/dl で安定していた．経口摄取開始 後のインスリン必要量は術前とほぼ同量であった。術 後の経過は良好で，合併症の発生はみられず，第47病 日に退院した。

\section{考察}

各種画像診断の進歩に伴い、これまで比較的稀とさ れてきた膵変胞性疾患の発見される頻度が增し，既存 の分類法や発生機序などの病理学的問題や治療方針な どについて論じられる機会が増えつつある122).

萃襄胞腺癌は, 初めから癌として発生することは稀 で，通常先行する衰胞腺腫から発生すると考えられて いる(1)3. 本症例において子，組織学的に，明らかな高 分化型腺癌の像のはかに，異型度の低い腺腫の部分， より異型度の高い細胞の丈の低い乳頭状増殖巣など分 化度の異なる部分が共存し, 腺腫からの癌化と考えて 矛盾はない，本症例は，4年前に他医にて精査をらけ ており，この時の所見は病変の発生を考えるうえで興 味深い，4年前の時点で既に発癌があったのか否かは 不明であるが，少なくとも基胞は小さく，主たる所見 はERCPに拈ける主膵管のびまん性の拡張と一部の


ていた，平成元年に腹部 CT 唡查を行っているが，こ の時の所見はその 2 年前の所見と大差がなく積極的に 腫瘍性衰胞を疑う所見に乏しかった，本症例における 病変の発生過程は，これら過去の検査所見々今回の切 除標本に打ける病変の部位と組織所見から，主膆管と の交通がある分枝抁張膵管からの発癌と推定される。 また，少なくとも 2 年前には膵頭部に大きな莀胞の存 在は認めず，癌の発育と同時に蘛胞む発育したと考兄 られる。

膵要胞性疾患の治療方針は，その発生過程や病理学 的分類が明確でないため, 未たに確立されてはいない。

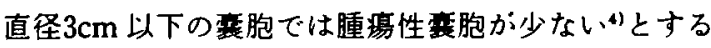
報告むあるが，本来黄胞の大きさと癌化とは無関係と 考えられる. 本症例においてもその発生過程で述べた ごとく癌の発育と同時に慗胞も增大したと推定され， 実際，小零胞での発癌例 ${ }^{5}$ p経過観察中に装胞が縮小 した悪性例も報告されており ，算胞が小さい場合で

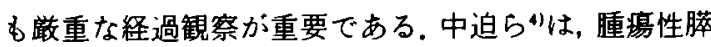

算胞と診断する一つの根拠として，ERCP で丵胞の成 因にかかわる疾患を認めないことをあげているが，本 症例のように，慢性脺炎に合併した膵爱胞であるから といって腫㑥性衰胞を否定することはできない，現時 点では，文献的にも粘液性膵紘胞腺腫からの発癌はか なり高率78)と考えられ，睡湯性膵衰胞之診断された場 合やそれを否定できない場合には切除の適応はあるす のと考えられる。

脺切除にあたっては, 脺重胞腺癌の進展様式や比較 的良好な予後から，可能な限り膵全摘術は行わず，膵 実質を温存すべきであると考えられる"が，本症例の ごとく肉眼的に腫場の境界を判断することが困難な場 合もある.このような場合は，術中迅速組織診断を積 極的に行うべきであり，各施設に招いてかかるシステ ムの確立に務める必要があると考えている。

$$
\text { 結語 }
$$

4 年間にわたり経過を観察し，臨床経過および病理 組織像から分枝払張脺管から発生したと考えられる粘 液性膵变胞腺癌の 1 例について報告した。

\section{文献}

1）黑田 慧，杉山政則：膵宾胞性病変・疾患の臨床病 理学的課題, 消外 $15: 427-437,1992$

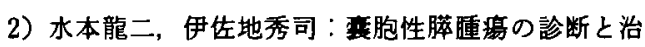
療, 消外 $14: 671-682,1991$

3）柳澤昭夫，加藤 洋：膵の上皮性腫湯性塞胞の分 類, 消外 $15: 421-426,1992$

4）中迫利明，羽生富士夫，今泉俊秀他：膵烡胞性疾患 の爁別診断, 胆と膆 $11: 53-60,1990$

5）秋山高儀, 福島 亘, 徳重広幸他：脺烡胞腺癌の 1 例, 胆と脺 $11: 1421-1425,1990$

6）加納宣康，山田直樹，古村能章他：経過観察中に謈

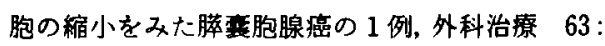
230-233, 1990

7) Compagno J, Oertel JE: Mucinous cystic neoplasm of the pancreas with overt and latent malignancy (cystadenocarcinoma and cystadenoma). Am J Clin Pathol 69: 573-580, 1978

8) Katoh H, Rossi RL, Braasch JW, et al: Cystadenoma and cystadenocarcinoma of the pancreas. Hepato-gastroenterol 36 : 424-430, 1989

9）網倉克己, 古川 徹, 小針雅男他：粘液産生膡重場 の外科治療，消外 $15: 463-470,1992$ 


\title{
A CASE OF MUCINOUS CYSTADENOCARCINOMA OF THE PANCREAS TREATED BY TOTAL PANCREATECTOMY AFTER A FOUR.YEAR FOLLOW-UP
}

\author{
Tsutomu SATO, Katsuhiko SUZUKI, Kanji KOMATSU", Makoto MURATA", Hideki WAKAMATSU", \\ Yoshihiro ASANUMA ${ }^{21}$, Hiroshi NANJO ${ }^{21}$ and Kenji KOYAMA ${ }^{2}$ \\ Department of Surgery and Gastroenterology ", Honjo First Hospital \\ First Department of Surgery, Akita University School of Medicine2 ${ }^{21}$
}

A case of mucinous cystadenocarcinoma of the pancreas which was treated by total pancreatectomy after a 4-year follow-up period was experienced. In this paper the process of the tumor growth and appropriate treatment are described. A 78-year-old woman was admitted to the hospital because of epigastric discomfort. She had been diagnosed as having a pancreatic cyst, $1.5 \mathrm{~cm}$ in diameter, associated with chronic pancreatitis at elsewhere 4 years before, and was followed on by abdominal CT and echogram every 2 years. On admission to the hospital, CT and echogram revealed the enlarged cystic lesion with a diameter of $6.0 \mathrm{~cm}$ at the head and body of the pancreas. She was diagnosed as having a mucinous cystadenocarcinoma. Total pancreatectomy was carried out because multiple small cysts were observed in the pancreatic body and tail. Histologically, the tumor was composed of several different components such as papillary growth of well differentiated adenocarcinoma, cluster of atypical cells and simple columnar lining cells without atypia, and cancerous change of the cystadenoma was highly suspected. 